\title{
THE SURVIVAL OF FACTOR VIII (ANTIHEMOPHILIC GLOBULIN) AND FACTOR IX (PLASMA THROMBOPLASTIN COMPONENT) IN NORMAL HUMANS *
}

\author{
By EDWARD ADELSON, JACK J. RHEINGOLD, OLIVE PARKER, MANFRED \\ STEINER, AND JAMES C. KIRBY
}

\author{
(From the Department of Medicine, George Washington University Medical School, \\ Washington, D. C.)
}

(Submitted for publication November 16, 1962; accepted February 28, 1963)

There is much evidence favoring the concept of coagulation as a continuous process in the normal subject. In order to learn more about the dynamics of this process, we have been studying the survival of physiological amounts of the various clotting factors in the normal subject. With the development of isotope labeling, it has for the first time become possible to carry out such studies. We (1-3) and others (4-10) have applied this technique to studies of platelet and fibrinogen turnover. These studies were possible because both platelets and fibrinogen are present in large amounts and can be separated in relatively pure form. Isotope techniques have not yet been applied to a study of the other proteins involved in coagulation because they are present in relatively trace amounts and cannot yet be isolated in sufficiently pure form.

In order to overcome these problems, we have developed a technique of in vivo labeling, separating, and counting two of the clotting proteins, Factor VIII (antihemophilic globulin) as an example of a protein consumed during coagulation and Factor IX (plasma thromboplastin component, Christmas factor) as an example of a clotting protein not consumed during coagulation.

\section{METHODS}

In vivo labeling. Because of the extremely labile nature of many of the clotting factors, we used a labeling method that involves minimal in vitro manipulation. We

* Supported by U. S. Public Health Service grant HE-02274-08 and by U. S. Army contracts DA 49-193MD-2273 and DA 49-193-MD-2325. Presented in part at the Third Annual Meeting of the American Society of Hematology, November 28-30, 1960, in Montreal, Canada, and at the Annual Meeting, Eastern Section American Federation for Clinical Research, January 6-7, 1961, in Bethesda, Md. also selected a structural rather than an adsorbed label, since the latter involves the risk of denaturation and of elution. Our technique is a modification of the method of Volwiler and associates (8). $\mathrm{S}^{35}$-DL-methionine was obtained as a dry powder with high specific activity (21.4 $\mu \mathrm{c}$ per $\mathrm{mg}) .^{1}$ This material was dissolved in sterile, pyrogen-free saline and passed through a $0.45 \mu$ Millipore filter to insure sterility of the final product.

Three $\mathrm{mc}$ of $\mathrm{S}^{35}$-DL-methionine was injected intravenously into suitable humans. Subjects were selected who had no evidence of liver disease or of bleeding tendency. The labeled amino acid was used by the recipient in the formation of plasma proteins. The more rapid the turnover of the protein, the higher the specific activity would be. Twenty-four hours later, the subject was phlebotomized. ACD solution was used as anticoagulant, and $500 \mathrm{ml}$ of blood was obtained with as little trauma as possible. The blood was immediately infused into the normal human recipients in whom the survival of the labeled protein was to be followed.

Separating labeled proteins. This was accomplished by immunological methods.

A partially purified Factor VIII preparation was made from human plasma by the method of Spaet and Kinsell (11). This mixture of proteins was made into a $10 \%$ solution with distilled water and mixed in a $1: 1$ suspension with Freund adjuvant. ${ }^{2}$ The mixture was injected intramuscularly twice a week for a period of 2 months into a group of twelve rabbits. After a 10-day rest period, the rabbits each received an iv injection of $3 \mathrm{ml}$ of an alum-precipitated preparation made from a $5 \%$ solution of the original partially purified Factor VIII preparation. Seven days later, the rabbits were bled into 0.1 vol of $0.1 \mathrm{M}$ sodium oxalate, the plasmas were separated and pooled, and 0.1 vol of $0.1 \%$ aqueous merthiolate was added.

Blood was drawn from a patient with hemophilia whose Factor VIII level when measured by the partial thromboplastin technique (12) was less than $1 \%$. This blood was drawn into 0.1 vol of $0.1 \mathrm{M}$ sodium oxalate, and 0.1 vol of $0.1 \%$ aqueous merthiolate was added.

1 Obtained commercially from Nuclear Chicago Corp., Des Plaines, Ill.

2 Obtained commercially from Difco Laboratories, Detroit, Mich. 
Serial dilutions of the two plasmas were then mixed with each other in microprecipitin tubes and incubated for 2 hours at room temperature and then for 48 hours at $4^{\circ} \mathrm{C}$. The ratio of plasmas that formed maximal precipitins was noted. Frequently the precipitin took the full 48 hours to form completely. Further incubation produced no additional precipitin. The entire batch of pooled rabbit plasma was then mixed with the hemophilic plasma at this ideal ratio. The precipitin that developed was removed by centrifugation, and the entire process of adsorption was repeated, first with samples in microprecipitin pilot tubes, then with the entire batch. After three or four adsorptions, a mixture was obtained which, on addition of more hemophilic plasma from the original donor and from other hemophilic donors, produced no further precipitin.

This antibody was then set up in serial dilutions in microprecipitin tubes against serial dilutions of normal human plasma. The supernatant fluids of these tubes were then divided into two portions, one of which was set up against excess antigen (normal plasma), the other of which was set up against excess antibody (absorbed rabbit plasma). Those tubes that showed no precipitin against both excess antigen and excess antibody were considered to be at the ideal antigen-antibody ratio, and later mixtures of the antibody with normal human plasma were first set up at this ratio. In order to insure complete precipitation of Factor VIII, supernatant fluids of these mixtures were always brought into the zone of antibody excess by the addition of more antibody.

To test the efficacy of this antibody in forming an insoluble precipitin with Factor VIII, an experiment was carried out in which two tubes were prepared as follows. Tube 1 contained a mixture of normal plasma plus purified antibody at the ideal ratio; tube 2 contained the same amount of normal plasma plus normal rabbit plasma that had no antibody against Factor VIII and that had been aged as long as the rabbit antibody (so as to remove rabbit Factor VIII). The two tubes were incubated in an identical manner. The precipitin which formed in tube 1 was removed by centrifugation. No precipitin formed in tube 2. Factor VIII activity was then determined in both tubes by the partial thromboplastin test. Tube 1 showed less than $1 \%$ of the original Factor VIII activity; tube 2 showed $70 \%$ of the original activity. This data confirmed that the antibody formed a precipitin with essentially all the Factor VIII in normal plasma.

A rabbit antibody specific for Factor IX was prepared in a similar manner. Partially purified Factor IX was prepared by the method of Lewis and Didisheim (13) This material was combined with Freund adjuvant and injected into a group of rabbits in a manner similar to that described for Factor VIII. In this instance, the immunized rabbit was used as a source of serum rather than plasma. To this serum, 0.1 vol of $0.1 \%$ aqueous merthiolate was added. The serum was repeatedly adsorbed against the serum of a patient markedly deficient in Factor IX. The final product was set up against normal serum to determine the ideal ratio of serum to antibody.
When normal serum was mixed with this antibody at the ideal ratio, Factor IX activity disappeared from the supernatant fluid as measured by a modification of the thromboplastin generation test (14). This confirmed that the antibody forms a precipitin with nearly all the Factor IX in normal serum.

Counting the radioactive protein. After the plasma containing radioactive proteins was infused into normal human recipients, samples of blood were obtained at suitable intervals. The radioactive Factor VIII was separated from $10-\mathrm{ml}$ plasma samples by the specific Factor VIII antibody, and the radioactive Factor IX was separated from $10-\mathrm{ml}$ plasma samples by the specific Factor IX antibody. The resultant precipitins were washed four times in distilled water and transferred into previously weighed, $20-\mathrm{ml}$, liquid-scintillation counting vials. The precipitin was dried under a stream of air. The vials were weighed again so that the weight of precipitin was known. The precipitins were then put into suspensionsolution in toluene counting fluid by adding $0.5 \mathrm{ml}$ of hyamine detergent (hydroxide of hyamine 10-X, $1 \mathrm{M}$ solution in methanol) ${ }^{3}$ (15) to the precipitin. To the precipitin-hyamine mixture was added $19.5 \mathrm{ml}$ of toluene containing the scintillator and the fluor-4 g PPO (2,5diphenyloxazole) and $100 \mathrm{mg}$ POPOP [1,4-bis-2-(5phenyloxazolylbenzene)] per liter of toluene. The vials were then cooled, dark adapted, and counted in the Packard Tri-Carb liquid scintillation counter.

During the early phases of this work, results were expressed as counts per minute per milligram of precipitin. Since the weight of precipitin per unit volume of plasma did not vary significantly from sample to sample, however, the data were later expressed as counts per minute per $10-\mathrm{ml}$ sample of plasma or serum. These counts were plotted on semilog graph against time posttransfusion. The ideal curve for each survival study was obtained by least-squares fitting to the sums of the exponentials by means of a digital computer $(16,17)$. The slopes and intercepts were obtained by this least-squares procedure with normal equations. This method also yielded the variances and covariances for the slopes and intercepts. The standard error of estimate was then calculated as the square root of the variances. This figure gives an indication of the amount of scatter of the points about the theoretical lines.

\section{RESULTS}

Counting efficiency with the hyamine toluenePPO-POPOP counting system was determined by a standard of $\mathrm{C}^{14}$-benzoic acid. $\mathrm{C}^{14}$ (and therefore $\mathrm{S}^{35}$ ) had a counting efficiency of $72 \%$. The quenching effect of the added protein was determined by internal standardization, and was between 1 and $3 \%$ in all samples. The $72 \%$ counting efficiency for $S^{35}$ proved adequate to obtain

\footnotetext{
3 Obtained commercially from Packard Instrument Co., La Grange, III.
} 


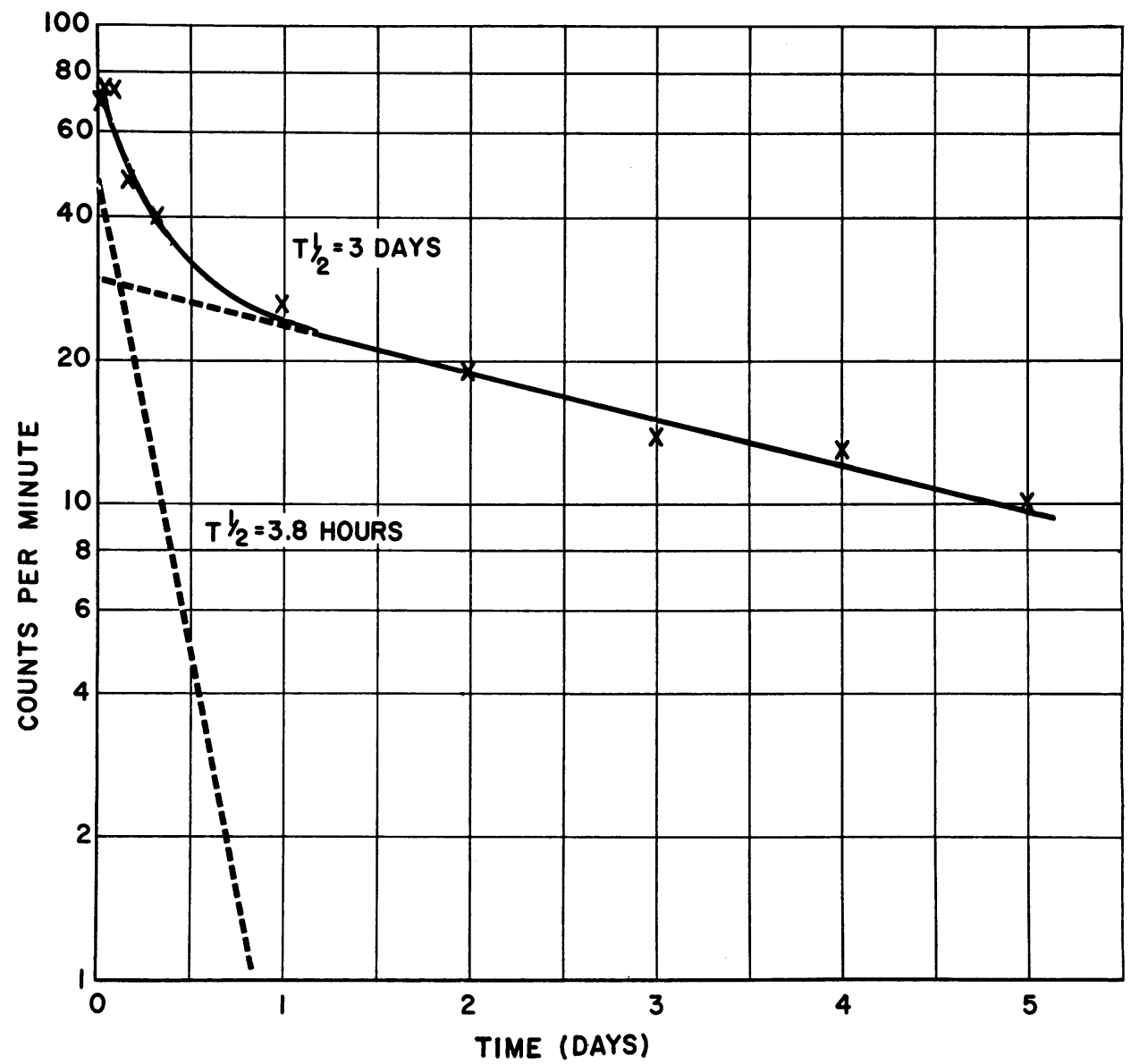

Fig. 1. Survival of Factor VIII in normal human Recipient 1. Semilog graph. Counts per minute for Factor VIII separated from 10-ml samples of plasma are plotted against time after transfusion.

survival curves for the two proteins under study. The counts at 10 minutes after transfusion ranged from 70 to $120 \mathrm{cpm}$ above background.

Figure 1 shows the survival curve for Factor VIII in normal Recipient 1 . This is a typical survival curve. It shows two exponential compo-

TABLE I

Half-lives and standard errors of estimate of the second components of the Factor VIII survival curves in five normal human recipients

\begin{tabular}{ccc}
\hline \hline $\begin{array}{c}\text { Factor } \\
\text { VIII } \\
\text { Recipient } \\
\text { no. }\end{array}$ & $\begin{array}{c}\text { Half-life of } \\
\text { second } \\
\text { component }\end{array}$ & $\begin{array}{c}\text { Standard error } \\
\text { of estimate }\end{array}$ \\
\hline & days & days \\
1 & 3 & \pm 0.3 \\
2 & 1.6 & \pm 0.1 \\
3 & 1.9 & \pm 0.2 \\
4 & 3.2 & \pm 0.3 \\
5 & 3.8 & \pm 0.2 \\
\hline
\end{tabular}

nents. The first component has an apparent halflife of 8 hours when measured directly, but only 3.8 hours when the proper correction is made for the second component. The second component has a half-life of 3 days. In addition to the halflife data, Figure 1 shows that $60 \%$ of the Factor VIII that was present at 10 minutes after infusion was lost in phase 1 , and $40 \%$ was lost in phase 2. This will be discussed later.

Figure 2 shows the survival curve for Factor VIII in normal Recipient 4. This survival curve, beginning on the first day after transfusion, has a half-life of 3.2 days. The half-life of the first component was not determined in Recipients 2 through 5 because of insufficient antibody.

Table I shows the results of all five of the Factor VIII survival studies. The half-life of the second component ranged from 1.6 days to 3.8 days, with a weighted mean average of 2.9 days. 
As seen from an inspection of Figures 1 and 2, and from the standard errors of estimate in Table $\mathrm{I}$, there was some scatter of the points. This is an inevitable difficulty when dealing with minute amounts of protein with low specific activity.

By drawing a sample from the radioactive blood transfused into the recipient, the number of counts per minute of radioactive Factor VIII infused into the recipient was determined. We then estimated blood volume in the recipient by standard height-weight charts. We calculated what the theoretical counts per minute of Factor VIII radioactivity per milliliter of whole blood should have been at time zero. In Recipient 1 this was $30 \%$ above the levels found by extrapolation of the experimental data to time zero. The implication of this finding will be discussed later.
Figure 3 shows the Factor IX survival curve in Recipient 1. Once again we see two exponential components. In Figure 3, the first component has a corrected half-life of 22 hours, and the second component has a half-life of 9.9 days. Figure 4 shows the Factor IX survival curve in Recipient 3 . Here, the first component has a corrected half-life of 26 hours, and the second component has a half-life of 7.6 days.

Table II shows the results of all five of the Factor IX, phase one survival studies. The corrected half-lives range from 13.2 to 26 hours, with a weighted mean average of 15.1 hours.

Table III shows the results of all five of the Factor IX, phase two survival studies. The halflives range from 6.7 to 12 days, with a weighted mean average of 8.4 days. Once again there is

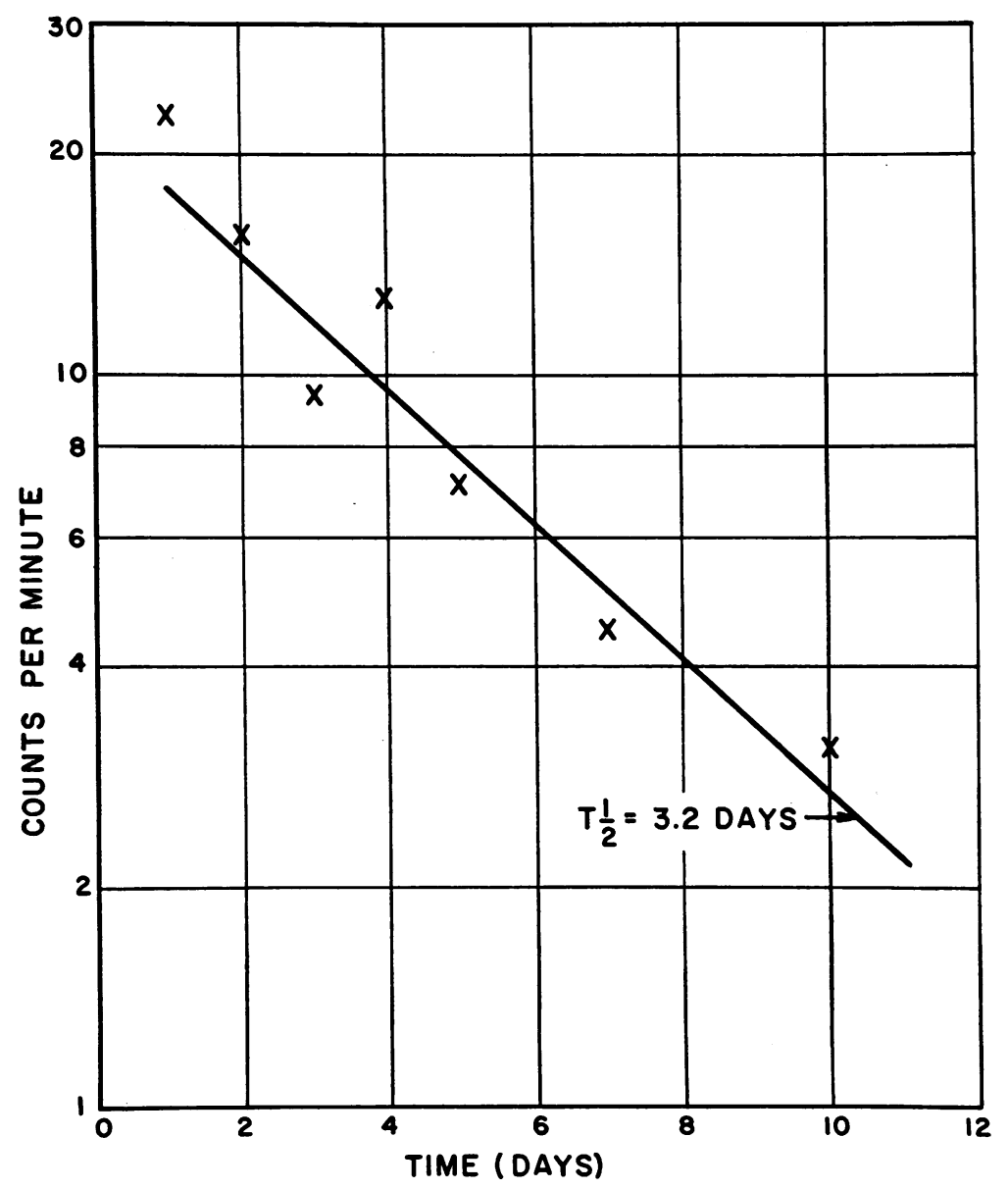

Fig. 2. Survival of Factor VIII in normal human Recipient 4. Semilog graph. Counts per minute for Factor VIII separated from 10-ml samples of plasma are plotted against time after transfusion. No attempt was made to obtain the first component of the survival curve. 


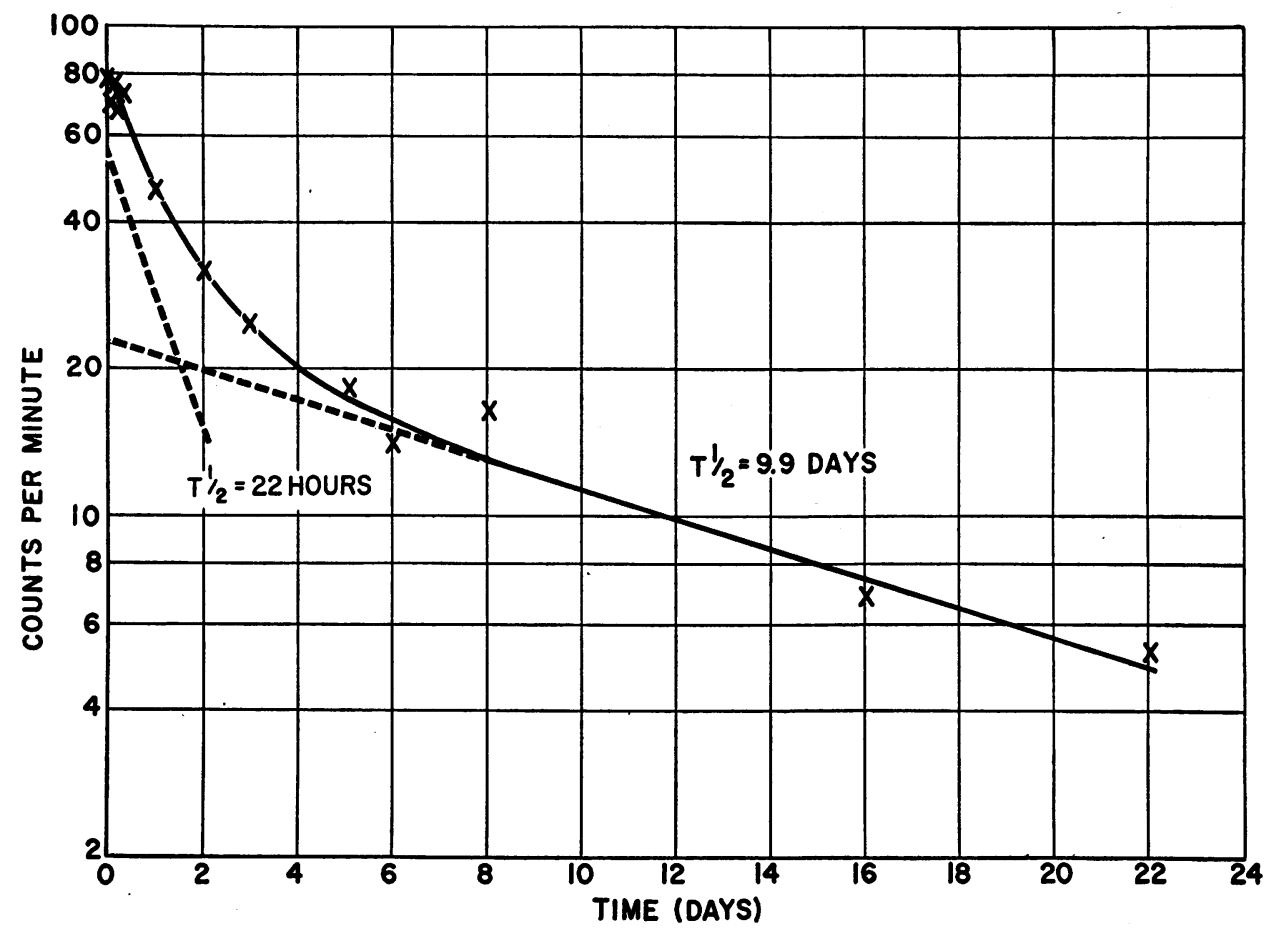

Fig. 3. Survival of Factor IX in normal human Recipient 1. Semilog graph. Counts per minute for Factor IX separated from $10-\mathrm{ml}$ samples of serum are plotted against time after transfusion.

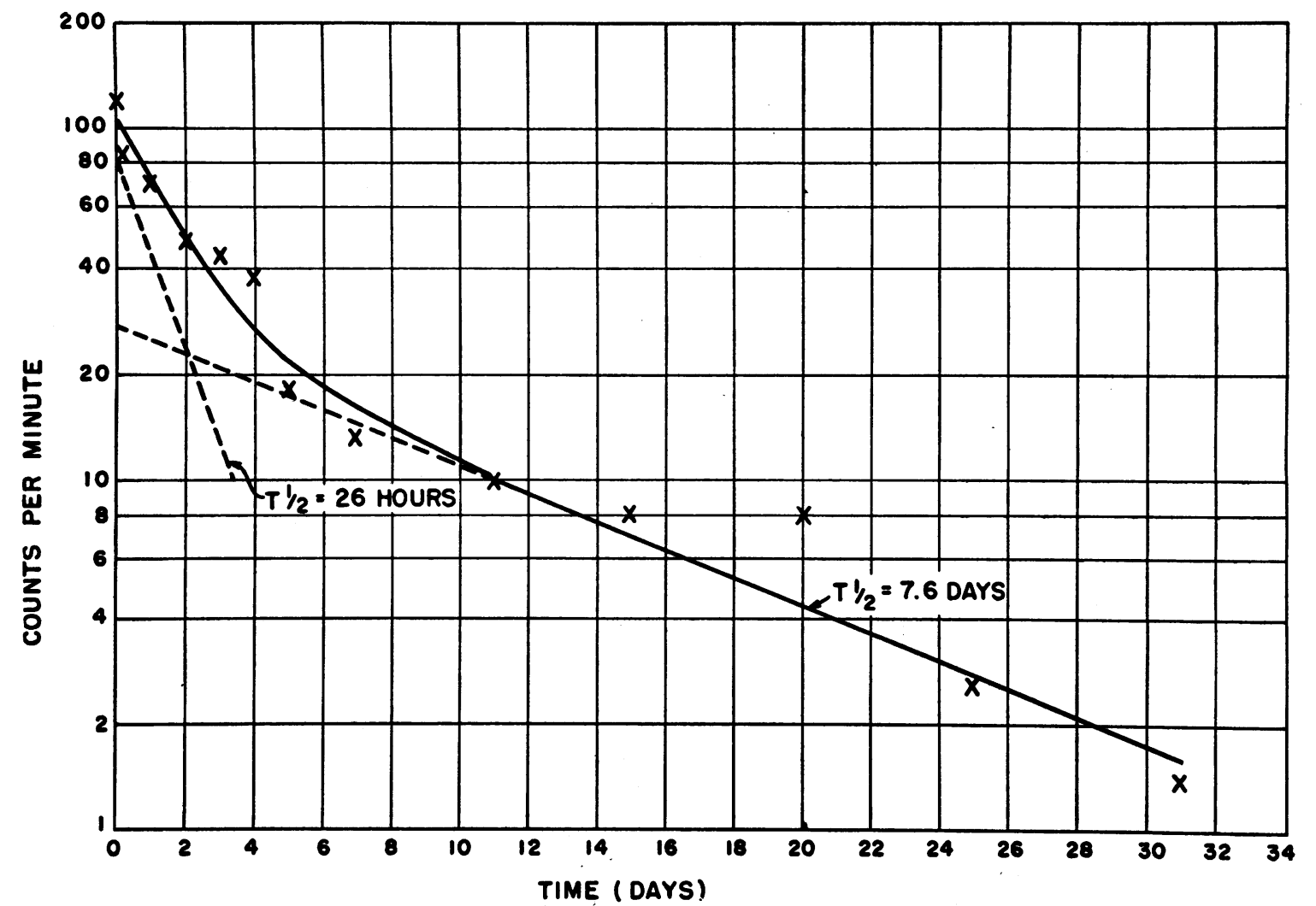

Fig. 4. Survival of Factor IX in normal human Recipient 3. Semilog graph. Counts per minute for Factor IX separated from 10-ml samples of serum are plotted against time after transfusion. 
TABLE II

Half-lives and standard errors of estimate of the first components of Factor IX survival curves in five normal human recipients

\begin{tabular}{ccc}
\hline $\begin{array}{c}\text { Factor } \\
\text { IX } \\
\text { recipient } \\
\text { no. }\end{array}$ & $\begin{array}{c}\text { Corrected } \\
\text { half-life } \\
\text { of first } \\
\text { component }\end{array}$ & $\begin{array}{c}\text { Standard error } \\
\text { of estimate }\end{array}$ \\
\hline 1 & hrs & hrs \\
2 & 22 & \pm 3.5 \\
3 & 13.2 & \pm 4.0 \\
4 & 26 & \pm 5.5 \\
5 & 13 & \pm 0.9 \\
5 & 15 & \pm 6
\end{tabular}

scatter of the points as seen in Figures 3 and 4, and by the standard errors of estimate in Tables II and III.

In the Factor IX survival curves, approximately $70 \%$ of material present 10 minutes after infusion was consumed in phase one, and $30 \%$ was consumed in phase two. This is comparable to the findings for Factor VIII.

The theoretical $100 \%$ recoveries were determined for Factor IX as they had been for Factor VIII, and again the theoretical levels averaged $30 \%$ above the levels found by extrapolation of experimental data to time zero.

\section{DISCUSSION}

In both our Factor VIII and Factor IX survival studies, $30 \%$ of the transfused material had disappeared from the circulating blood by the time the first sample was drawn at 10 minutes after transfusion. It is most unlikely that this disappearance is due to denaturation of the protein by the labeling technique, since the label is an in vivo one. In the case of Factor VIII, the process of phlebotomy and transfusion may have led to some denaturation of the labile protein. This explanation, however, would not apply to Factor IX, which is fairly stable. Hoag, Aggeler, and Fowell (18) in their study of Factor IX survival drew multiple samples during the early phase after transfusion and noted a rapid disappearance of Factor IX during the first 20 minutes after transfusion. Unfortunately, we did not study this very early phase. In our studies the transfusion itself usually required 60 minutes, so that a 10-minute posttransfusion sample was actually drawn 70 minutes after the start of the transfusion.
The survival curves we obtained for Factor VIII and Factor IX transfused into normal recipients are biphasic exponential curves. We interpret phase one as reflecting equilibration between intravascular and extravascular compartments. We interpret phase two as reflecting the true rate of utilization of the proteins. In studies of Factor VIII survival in hemophilics, Wagner and associates (19) and Shulman, Marder, and Hiller (20), using techniques that do not involve antibodies or isotopes, have also obtained biphasic exponential survival curves and have explained the first phase on the basis of equilibration between intravascular and extravascular compartments.

In 1951, Sterling (21) reported biphasic exponential curves for $I^{131}$-labeled albumin survival, and Wasserman and associates (22) demonstrated by thoracic duct catheterization that the first phase was associated with the appearance of the protein in the extravascular fluid. Since then, biphasic exponential curves have been found in most in vivo plasma protein survival studies $(8,9,23$, 24 ), and the first component is usually explained on the basis of equilibration between intravascular and extravascular compartments.

There are other possible explanations for the biphasic exponential curves we obtained. It may be that the $\mathrm{S}^{35}$-DL-methionine undergoes reutilization. In this case phase one would be the true rate of utilization. The cross-transfusion technique, however, keeps reutilization to a minimum, since it reduces the total amount of $\mathrm{S}^{35}$-DL-methionine available to the recipient. Studies have been carried out $(25,26)$ with $\mathrm{S}^{35}$-DL-methionine-labeled gamma and beta globulins. These studies indicate that with cross-transfusion methionine

TABLE III

Half-lives and standard errors of estimate of the second components of Factor IX survival curves in five normal human recipients

\begin{tabular}{ccc}
\hline \hline $\begin{array}{c}\text { Factor } \\
\text { IX } \\
\text { recipient } \\
\text { no. }\end{array}$ & $\begin{array}{c}\text { Half-life of } \\
\text { second } \\
\text { component }\end{array}$ & $\begin{array}{c}\text { Standard error } \\
\text { of estimate }\end{array}$ \\
\hline & days & days \\
1 & 9.9 & \pm 1 \\
2 & 12 & \pm 3.5 \\
3 & 7.6 & \pm 0.7 \\
4 & 7.6 & \pm 0.8 \\
5 & 6.7 & \pm 1.7 \\
\hline
\end{tabular}


reutilization does not alter the survival curve until approximately 30 days posttransfusion.

Another explanation for the biphasic nature of the survival curves could be impurity of the antibodies used to separate the plasma proteins with which we are concerned. If the antibodies each separate two proteins, each curve would be biphasic. We consider this explanation to be most unlikely in view of complete absorption of any contaminant antibodies by the addition of plasma from patients lacking the single factor being tested.

If one considers the radioactive protein present 10 minutes posttransfusion as $100 \%$, then $60 \%$ of Factor VIII enters the extravascular pool and is lost during phase one. The extravascular pool must therefore hold at least 1.5 times the Factor VIII present in the intravascular pool. In the case of Factor IX, approximately $70 \%$ or 2.3 times the amount present in the intravascular pool is in the extravascular pool. The existence of this extravascular pool has been lost sight of in many studies of in vivo survival of clotting factors (27). This concept has important significance in clinical medicine. If we are to use replacement therapy for treatment of a hemorrhagic episode in classical hemophilia or in Christmas disease, we should start the therapy with sufficient Factor VIII or Factor IX to overcome the large loss of the transfused proteins into the extravascular space. Then the Factor VIII or IX levels will decrease by the relatively slow half-life of the second (utilization) phase. This therapeutic approach has recently been re-emphasized by Brinkhous (28).

The half-life of the equilibration phase of Factor VIII survival (3.8 hours) is much shorter than that for Factor IX equilibration (15.1 hours). Both of these rates of equilibration are much shorter than the 26-hour half-life we previously reported (3) for the equilibration phase of fibrinogen survival.

The 2.9 day half-life of the second phase of Factor VIII survival curves that we observed is longer than the 25 hours reported by Wagner and associates (19) for hemophilic dogs and the 9 to 11 hours reported by Shulman and co-workers (20) for hemophilic humans. We do not know whether our survivals are longer because of the difference in technique of measurement or because of an increased rate of utilization of Factor VIII in hemophilic subjects as compared with normals.
The 8.4 day half-life of the second phase of our Factor IX survival curves is strikingly different from the 1- to 4-hour half-life reported by Hoag and colleagues (18). These authors, however, did not follow the Factor IX survival curve beyond 7 hours posttransfusion. Therefore, what they call the second phase of their survival curves corresponds to our first phase and cannot be compared to the second phase of our curves, which we consider the utilization phase.

The technique that we report here is a difficult one. Each blood sample undergoes many manipulations over a period of many days. As a result there is a significant amount of scatter of the points in each survival curve. With the digital computer, it was possible to obtain a least-squares fit to the sums of the exponentials. The standard errors of estimate of the half-life results in $\mathrm{Ta}$ bles I, II, and III give some indication of the variability of the data. In spite of this variability, and in spite of the technical difficulties, we believe this method has value, since there is no other currently available technique to measure the survival of physiological amounts of clotting proteins in normal humans.

\section{SUMMARY}

1. A technique has been developed for studying the survival of plasma proteins transfused into normal human recipients. This technique has been applied to a study of the survival of two of the clotting proteins, Factor VIII and Factor IX, in normal humans.

2. The survival curves are biphasic with two exponential components. The first component is interpreted as due to equilibration between intravascular and extravascular spaces. The second component is interpreted as the rate of utilization or destruction.

3. For Factor VIII, the first phase has a halflife of 3.8 hours; the second phase, a half-life of 2.9 days. For Factor IX, the first phase has a half-life of 15.1 hours; the second phase, a halflife of 8.4 days.

4. The size of the extravascular pool of Factor VIII is approximately 1.5 times the size of the intravascular pool. The extravascular pool for Factor IX is approximately 2.3 times the intravascular pool. The implications of this concept 
for the therapy of patients with classical hemophilia and Christmas disease are discussed.

\section{ACKNOWLEDGMENT}

The authors wish to express appreciation to Dr. Mones Berman of the National Institute of Arthritis and Metabolic Diseases, Bethesda, Md., for assistance with mathematical analyses of the data.

\section{REFERENCES}

1. Adelson, E., J. J. Rheingold, and W. H. Crosby. Studies of platelet survival by tagging in vivo with $\mathrm{P}^{32}$. J. Lab. clin. Med. 1957, 50, 570.

2. Adelson, E., J. J. Rheingold, and O. Parker. Platelet and fibrinogen sequestration. Blood 1960, 15, 596.

3. Adelson, E., J. J. Rheingold, O. Parker, A. Buenaventura, and W. H. Crosby. Platelet and fibrinogen survival in normal and abnormal states of coagulation. Blood 1961, 17, 267.

4. Aas, K. A., and F. H. Gardner. Survival of blood platelets labeled with chromium $^{51}$. J. clin. Invest. 1958, 37, 1257.

5. Leeksma, C. H. W., and J. A. Cohen. Determination of the life span of human blood platelets using labelled diisopropylfluorophosphonate. J. clin. Invest. 1956, 35, 964.

6. Odell, T. T., and B. Anderson. Production and life span of platelets in The Kinetics of Cellular Proliferation, F. Stohlman, Ed. New York, Grune \& Stratton, 1959, p. 278.

7. Baldini, M., N. Costea, and W. Dameshek. The viability of stored human platelets. Blood 1960, 16, 1669.

8. Volwiler, W., P. D. Goldsworth, M. P. MacMartin, P. A. Wood, I. R. Mackay, and K. Fremont-Smith. Biosynthetic determination with radioactive sulfur of turn-over rates of various plasma proteins in normal and cirrhotic man. J. clin. Invest. 1955, 34, 1126.

9. Madden, R. E., and R. G. Gould. The turnover rate of fibrinogen in the dog. J. biol. Chem. 1952, 196, 641.

10. Hammond, J. D. S., and D. Verel. Observations on the distribution and biological half-life of human fibrinogen. Brit. J. Haemat. 1959, 5, 431.

11. Spaet, T. H., and B. G. Kinsell. Properties of bovine anti-hemophilic factor. Proc. Soc. exp. Biol. (N. Y.) 1953, 84, 314.

12. Langdell, R. D., R. H. Wagner, and K. M. Brinkhous. Estimation of antihemophilic activity by the partial thromboplastin time technic in The Coagulation of Blood. Methods of Study, L. M. Tocantins, Ed. New York, Grune \& Stratton, 1959, p: 72.
13. Lewis, J. H., and P. Didisheim. Production of antihuman PTC and antihuman proconvertin in rabbits. Proc. Soc. exp. Biol. (N. Y.) 1956, 93, 429.

14. Barkhan, P. Christmas-factor activity of cord blood. Brit. J. Haemat. 1957, 3, 215.

15. Eisenberg, F., Jr. Round table on preparation of alkaline absorbent for radioactive $\mathrm{CO}_{2}$ in liquid scintillation counting in Liquid Scintillation Counting, C. G. Bell, Jr., and F. N. Hayes, Eds. New York, Pergamon Press, 1958, p. 123.

16. Berman, M., E. Shahn, and M. F. Weiss. The routine fitting of kinetic data to models: a mathematical formalism for digital computers. Biophys. J., 1962, 2, 275.

17. Berman, M., M. F. Weiss, and E. Shahn. Some formal approaches to the analysis of kinetic data in terms of linear compartmental systems. Biophys. J. 1962, 2, 289.

18. Hoag, M. S., P. M. Aggeler, and A. H. Fowell. Disappearance rate of concentrated proconvertin extracts in congenital and acquired hypoproconvertinemia. J. clin. Invest. 1960, 39, 554.

19. Wagner, R. H., R. D. Langdell, B. A. Richardson, R. A. Farrell, and K. M. Brinkhous. Antihemophilic factor (AHF) : plasma levels after administration of AHF preparations to hemophilic dogs. Proc. Soc. exp. Biol. (N. Y.) 1957, 96, 152.

20. Shulman, N. R., V. J. Marder, and M. C. Hiller. A new method for measuring minimum in vivo concentrations of Factor VIII applied in distribution and survival studies (abstract). J. clin. Invest. 1962, 41, 1401.

21. Sterling, K. The turnover rate of serum albumin in man as measured by $\mathrm{I}^{131}$-tagged albumin. J. clin. Invest. 1951, 30, 1228.

22. Wasserman, K., and H. S. Mayerson. Exchange of albumin between plasma and lymph. Amer. J. Physiol. 1951, 165, 15.

23. Gitlin, D., H. Latta, W. H. Batchelor, and C. A. Janeway. Experimental hypersensitivity in the rabbit. Disappearance rates of native and labelled heterologous proteins from the serum after intravenous injection. J. Immunol. 1951, 66, 451.

24. Dixon, F. J., S. C. Bukantz, and G. J. Dammin. The effect of sensitization and X-radiation on the metabolism of $\mathrm{I}^{131}$ labeled proteins. Science 1951, 113, 274.

25. Schultze, B., and W. Maurer. Über im Organismus des Kaninchens nach Injektion von $\mathrm{S}^{35}-\beta$-und- $\gamma$ Globulinen entstehende $\mathrm{S}^{25}$-Albumine. Biochem. $Z$. 1957, 329, 127.

26. Schultze, B. Biologische Halbwertszeit einzelner Globulin-Fractionen beim Kaninchen. Biochem. Z. 1957, 329, 144.

27. Aggeler, P. Physiological basis for transfusion therapy in hemorrhagic disorders: a critical review. Transfusion (Philad.) 1961, 1, 71.

28. Brinkhous, K. M. Ninth Congress of the International Society of Hematology, September, 1962, Mexico City, Mex. 